\title{
STRATEGI DAN KEBIJAKAN PENGELOLAAN TERUMBU KARANG COREMAP DI WILAYAH CORAL TRIANGLE DI INDONESIA TIMUR
}

\author{
Siti Hajar Suryawati dan Agus Heri Purnomo \\ Balai Besar Penelitian Sosial Ekonomi Kelautan dan Perikanan \\ JI. KS. Tubun Petamburan VI Jakarta 10260 \\ Telp. (021) 53650162, Fax. (021)53650159 \\ Email: siti_suryawati@yahoo.com
}

Diterima 6 September 2012 - Disetujui 23 November 2012

\begin{abstract}
ABSTRAK
Tulisan ini mengusulkan sejumlah rekomendasi untuk perbaikan pengelolaan sumber daya terumbu karang di wilayah Coral Triangle Indonesia, yang didasarkan atas hasil penelitian pada Tahun 2011, di lokasi-lokasi Coral Reef Rehabilitation and Management Program (COREMAP). COREMAP adalah program pengelolaan sumber daya terumbu karang yang merupakan wahana utama Kementerian Kelautan dan Perikanan untuk mengimplementasikan kebijakan pengelolaan terumbu karang. Kebijakan tersebut dilatar-belakangi oleh degradasi yang terjadi pada sumber daya terumbu karang dan besarnya potensi serta pentingnya fungsi dari aset alam tersebut. Metode yang diacu untuk penyusunan rekomendasi ini adalah analisis Sistem Sosial Ekologis (SES) dan analisis resiliensi yang mencakup perilaku positif dan negatif dalam pengelolaan sumber daya terumbu karang, dilanjutkan dengan analisis Multi Criteria Decision Making (MCDM) terhadap perilaku-perilaku pengelolaan negatif. Data dalam penelitian ini mencakup aspek sistem sosial-ekologi, kerentanan dan resiliensi, yang diperoleh dari 1.244 responden masyarakat yang dipilih secara purposive dan 182 responden tokoh yang diperoleh dengan teknik snowball serta data sekunder yang diperoleh dari kepustakaan dan dokumentasi terkait. Hasil penelitian ini secara umum merekomendasikan 4 (empat) perbaikan terhadap kebijakan pengelolaan yang ada. Keempat rekomendasi tersebut adalah: 1) Peningkatan efektivitas Kawasan Konservasi Laut Daerah (KKLD) atau Taman Wisata Air Laut (TWAL) melalui penguatan kerjasama masyarakat-pemerintah dalam upaya-upaya menciptakan mata pencaharian alternatif, terutama di sektor non konvensional seperti pariwisata; 2) Memfokuskan pada intensifikasi pembentukan lembaga keuangan yang mendukung permodalan usaha dan perbaikan teknologi; 3) Perbaikan sistem koordinasi pihak terkait dalam pengawasan terhadap sumber daya; dan 4) Perbaikan desain program sosialisasi penggunaan alat tangkap ramah lingkungan.
\end{abstract}

Kata Kunci: terumbu karang, strategi pengelolaan, COREMAP, wilayah timur Indonesia

\section{Abstract: COREMAP Strategy and Policy in The Management of Coral Reefs in Coral Triangle Region of Eastern Indonesia. By: Siti Hajar Suryawati and Agus Heri Purnomo.}

This paper proposes recommendations to improve management for the resource management in the Indonesian's part of Coral Triangle Area, based on a research carried out in the COREMAP locations in 2011. COREMAP is a program introduced by the Ministry of Marine Affairs and Fisheries to implement its policies on coral reef management and conservation. The policies concern the ongoing alarming degradation of the resource and the disappearing physical existence as well as functions of such natural capital. The research methods were Social Ecological System (SES) analysis and resilience analysis covering both negative and positive management practices, followed by a Multi Criteria Decision Making (MCDM) analysis of the negative management practices to come up with prioritized strategy recommendations. Data used consisted of social-ecological system, vulnerability and resilience aspects, collected from 1.244 respondents representing ordinary citizens selected purposively and 182 key persons which were determined 
following the snowball sampling technique, and secondary drawn upon the documented files of relevant institutions. In general, the recommendation proposed through this paper are as follows: 1) Increasing the effectiveness Regional Marine Conservation Area and Marine Tourism Park by strengthening community-government cooperation aimed at creating alternative livelihood, particularly the nonconventional sectors, more specifically tourism, 2) Focusing on the intensification of the establishment of financial institutions to facilitate better access for business capital provision and technological improvements; 3) improvement of coordination system among local influential institutions in controlling the resource; and 4) improved design of outreach programs on the use of environmentally friendly fishing gear.

Keywords: coral reef, strategy, management, COREMAP, Indonesian East Region

\section{PENDAHULUAN}

Salah satu sumber daya potensial di Indonesia adalah wilayah pesisir, yang merupakan wilayah peralihan antara daratan dan lautan. Sumber daya ini sangat besar didukung oleh adanya garis pantai sepanjang sekitar 81.000 km (Dahuri et al., 2001). Garis pantai yang panjang ini menyimpan potensi kekayaan sumber alam yang besar. Potensi itu diantaranya berupa potensi hayati dan non hayati, termasuk bahan mineral, perikanan, hutan mangrove, dan terumbu karang.

Luas terumbu karang di Indonesia hanya sekitar $15 \%$ dari luas terumbu karang dunia, namun tingkat keragaman jenis terumbu karang Indonesia yang sangat tinggi terutama dikawasan Maluku dan Sulawesi sehingga menjadikan Indonesia sebagai pusat kawasan terumbu karang dunia (Dahuri, 2003; Anonimous, 2004). Terumbu karang menyediakan habitat ekologis yang menyokong kehidupan hewan dengan kepadatan tertinggi di bumi (Reid et al., 2011).

Terumbu karang juga memiliki berbagai fungsi layanan penting di wilayah tropis dan subtropis. Indonesia memiliki sekitar 51.020 $\mathrm{km}^{2}$ terumbu karang yang mengalami kerusakan akibat fenomena alam maupun aktivitas manusia. Sumber daya terumbu karang di Indonesia juga merupakan yang terpenting di Kawasan Coral Triangle, dengan nilai total mencapai US\$ 2.3 milyar/tahun (Wilkinson, 2008; Rudianto, 2009), sehingga selain menghilangkan nilai ekonomis langsung yang terkait dengan penghidupan masyarakat, kerusakan terumbu karang juga bernilai kerugian materiil yang sangat besar yang terkait nilai-nilai lain termasuk nilai-nilai ekologisnya. Hal inilah yang membuat perikanan terumbu karang merupakan salah satu sumber penghidupan utama bagi masyarakat pesisir dan pulau-pulau kecil (King, 1995).

Kondisi terumbu karang di Indonesia yang ditunjukkan oleh persentase tutupan karang hidupnya disajikan pada Gambar 1. Pada Gambar tersebut dapat dilihat bahwa kondisi terumbu karang yang baik kurang dari 30 persen.

Berdasarkan pada besarnya urgensi untuk menjaga dan melindungi sumber daya tersebut, Kementerian Kelautan dan Perikanan meluncurkan berbagai program yang dimaksudkan untuk menyelamatkan sumber daya alam dan kepentingan masyarakat di atas. Salah satunya melalui Coral Reef Rehabilitation and Management Project (COREMAP) atau Proyek Rehabilitasi dan Pengelolaan Terumbu Karang. Program yang dilakukan oleh COREMAP telah mengimplementasikan berbagai kegiatan lapangan, namun hasil evaluasi terhadap program-program yang ada menunjukkan adanya berbagai kekurangan dalam hal pemilihan strategi maupun pelaksanaannya. Sebagai contoh, strategi penguatan kelembagaan di tingkat desa dan pelaksanaan program di lapangan terlihat rapuh karena penetapan lembaga pengelola, misalnya Peraturan Desa (Perdes) dan Daerah Pembudidaya Laut (DPL), sering tidak memperhatikan kepentingan masyarakat (Kasim, 2011). 


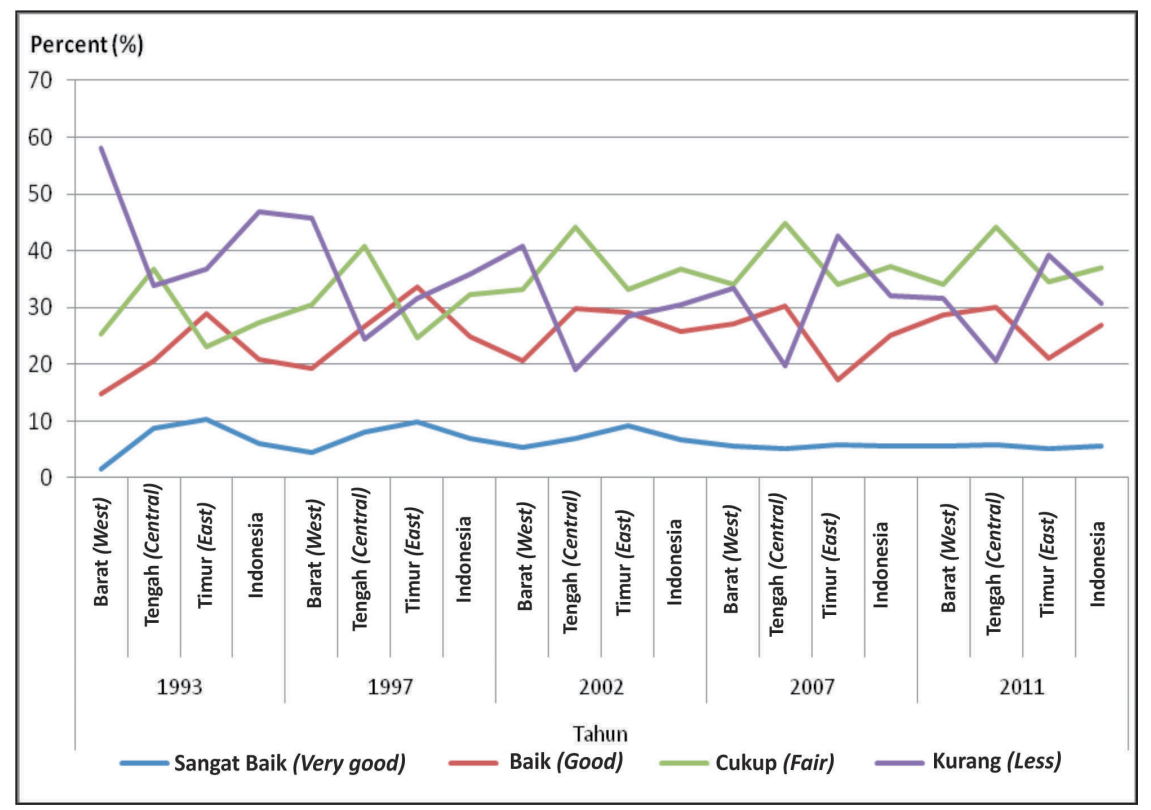

\section{Gambar 1. Kondisi Terumbu Karang di Indonesia (\% Tutupan Karang Hidup). Figure 1. Indonesian Coral Reef Condition (\% Live Coral Cover).}

Sumber: LIPI, 2011/ Source: LIPI, 2011

Terkait dengan itu, penelitian ini dimaksudkan untuk mengidentifikasi strategi pengelolaan sumber daya terumbu karang yang dikembangkan dalam COREMAP II. Dalam penelitian ini, upaya penyempurnaan dituangkan dalam penelaahan aspek-aspek yang kurang diperhatikan dalam penyusunan program COREMAP selama ini, yaitu aspek keterkaitan sistem sosial-ekologis, kerentanan dan resiliensi. Oleh karena itu, tulisan ini bertujuan mengkaji strategi yang dikembangkan dalam pengelolaan terumbu karang yang dilaksanakan oleh Kementerian Kelautan dan Perikanan melalui program COREMAP.

\section{METODOLOGI}

\section{Kerangka Pemikiran}

Pengelolaan sumber daya terumbu karang Kementerian Kelautan dan Perikanan yang dalam program COREMAP dituangkan dalam berbagai strategi yang dirumuskan berdasarkan pertimbangan dari berbagai faktor. Apabila pertimbangan-pertimbangan tersebut telah dilakukan secara cermat, maka dapat diharapkan bahwa kinerja dari program tersebut akan baik. Kenyataannya, program tersebut sejauh ini tidak memberikan dampak positif yang signifikan; di sisi lain, hasil penelitian menunjukkan bahwa terdapat berbagai aspek yang telah terabaikan dan menyebabkan kurang sempurnanya strategi yang diterapkan. Salah satu hal yang diduga telah terlewatkan dalam perumusan strategi COREMAP pada waktu yang lalu adalah keterkaitan antara sistem sosial dan sistem ekologis. Dengan memasukkan aspek tersebut dan aspek-aspek relevan lain, yang dilakukan melalui pendekatan analisis 'pengambilan keputusan multi kriteria' (MCDM), diharapkan strategi penyempurnaan akan dihasilkan dan diimplementasikan untuk program COREMAP di masa yang akan datang, sehingga kinerjanya dapat menjadi lebih baik. Secara diagramatis, kerangka pemikiran penelitian ini dapat dilihat pada Gambar 2. 


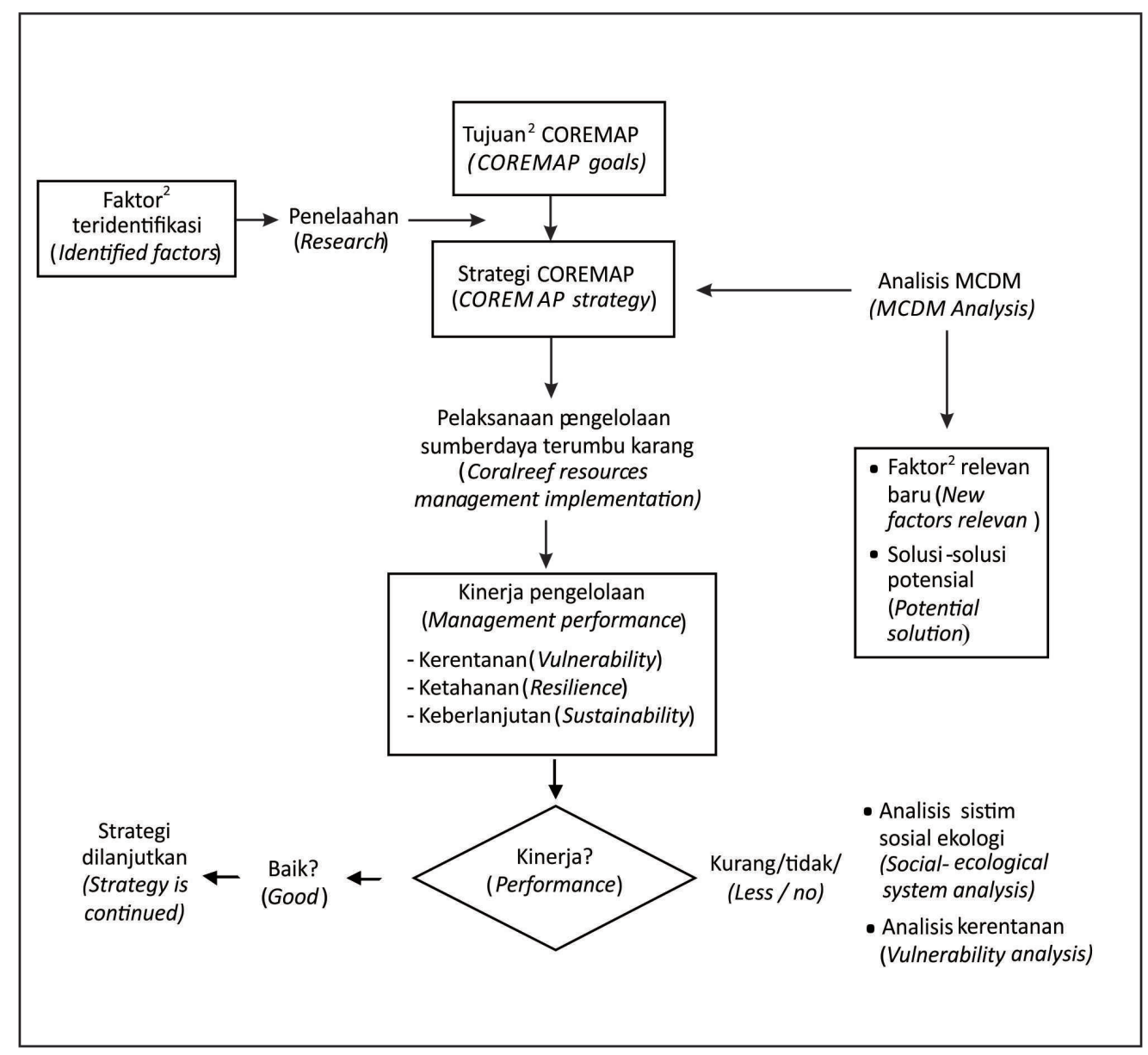

Gambar 2. Kerangka Analisis Pengelolaan Sumber daya Terumbu Karang di Kawasan Coral Triangle.

Figure 2. Analytical Framework of Resource Management in the Coral Triangle Area.

\section{Lokasi dan Waktu Penelitian}

Penelitian dilakukan pada bulan Januari - Desember 2011 di 7 (tujuh) kabupaten yang merupakan lokasi COREMAP pada 5 (lima) propinsi di wilayah Segitiga Karang di Indonesia Timur: 1) Kabupaten Pangkep, 2) Kabupaten Selayar, 3) Kabupaten Wakatobi, 4) Kabupaten Buton, 5) Kabupaten Sikka, 6) Kabupaten Biak; dan 7) Kabupaten Raja Ampat. Lokasi pengambilan sampel meliputi $10 \%$ dari jumlah kecamatan yang merupakan kecamatan-kecamatan yang menjadi cakupan program COREMAP.

\section{Jenis, Sumber dan Cara Pengumpulan Data}

Data yang dikumpulkan dalam penelitian ini berupa data primer maupun data sekunder. Data primer diperoleh melalui pengamatan langsung dan wawancara dengan responden dengan menggunakan daftar pertanyaan (kuesioner). Responden yang diamanti yaitu nelayan, pembudidaya, masyarakat umum dan tokoh masyarakat. Data yang diperoleh adalahdata-data tentang social-ecological sistem (SES) atau sistem sosial-ekologi, kerentanan dan resiliensi. Data sekunder, 
yang meliputi informasi tentang kondisi infrastruktur dan pelaksanaan program COREMAP diperoleh dari kepustakaan pemerintah maupun swasta yang terkait dengan penelitian. Jumlah sampel untuk responden yang mewakili masyarakat pelaku usaha diambil secara acak paling sedikit 30 orang dari tiap desa, sedangkan jumlah sampel yang mewakili tokoh tergantung pada kejenuhan informasi yang diperoleh melalui teknik wawancara snowball (Wahyono et al., 2001). Untuk wawancara dengan tokoh masyarakat, responden pertama ditetapkan melalui konsultasi dengan pejabat terkait di tingkat kabupaten, sedangkan responden berikutnya dipilih berdasarkan hasil informasi yang didapatkan dari responden sebelumnya. Dengan pendekatan itu, total responden adalah 1.426 orang (Tabel 1 ).

\section{Metode Analisis Data}

Untuk menyimpulkan perbaikanperbaikan yang diperlukan oleh program COREMAP yang akan datang, analisis dalam penelitian ini menempatkan pengelolaan sumber daya alam sebagai masalah yang multi kriteria dan multi objektif sehingga memerlukan teknik evaluasi yang saling berhubungan untuk mendukung proses pembuatan keputusan dalam pengelolaan sumber daya alam. Teknik MCDM (multi criteria decision making) (Anonimous, 1996) dipilih sebagai alat untuk melakukan proses seleksi yang melibatkan beragam kriteria (multi criteria) dalam pemilihan strategi alternatif (Gumbriech, 1996).

Pilihan-pilihan strategi alternatif yang diperoleh dari hasil penelitian Purnomo et al (2011) tentang analisis SES (Anderies et al., 2004), kerentanan (Binder and Dalton, 2011) dan resiliensi (Berkes et al., 2003) adalah: 1) penguatan kerjasama masyarakatpemerintah; 2) intensifikasi pembentukan lembaga-lembaga keuangan; 3) perbaikan sistem koordinasi; dan 4) perbaikan desain program sosialisasi. Analisis SES mencakup sumber daya, pengguna sumber daya, prasarana dan penyedia prasarana. Analisis kerentanan meliputi exposure, sensitivitas dan kapasitas adaptasi. Analisis resiliensi terdiri dari kemampuan belajar hidup dalam perubahan dan ketidakpastian, kemampuan mengembangkan diversitas yang memungkinkan reorganisasi dan pembaruan, kemampuan memanfaatkan berbagai macam pengetahuan secara terpadu dan kemampuan menciptakan peluang pengorganisasian diri.

Dari hasil analisis SES, kerentanan dan resiliensi diperoleh sejumlah faktor yang berdampak pada pengelolaan sumber daya yang mempengaruhi dinamika sosial, ekonomi dan ekologi. Faktor-faktor tersebut menjadi bagian utama perumusan strategi-strategi pengelolaan melalui analisis MCDM dengan software Criterium Decision Plus menggunakan metode Simple Multi Attribute Rating Technicue (SMART) (Edward and Barron, 1994).

Tabel 1. Cakupan dan Jumlah Responden.

Tabel 1. Coverage and Number of Respondents.

\begin{tabular}{|c|c|c|c|c|c|c|c|c|}
\hline \multirow{2}{*}{$\begin{array}{l}\text { Responden/ } \\
\text { Respondents }\end{array}$} & \multicolumn{7}{|c|}{ Kabupaten/ Regency } & \multirow{2}{*}{$\begin{array}{c}\text { Jumlah/ } \\
\text { Total }\end{array}$} \\
\hline & Pangkep & Selayar & Wakatobi & Buton & Sikka & Biak & $\begin{array}{c}\text { Raja } \\
\text { Ampat }\end{array}$ & \\
\hline $\begin{array}{l}\text { Nelayan, pembudidaya } \\
\text { dan masyarakat umum/ } \\
\text { Fisher, aquaculturist } \\
\text { and general society }\end{array}$ & 133 & 152 & 276 & 114 & 344 & 45 & 180 & 1.244 \\
\hline $\begin{array}{l}\text { Tokoh masyarakat/ } \\
\text { Key informan }\end{array}$ & 20 & 10 & 35 & 19 & 43 & 27 & 28 & 182 \\
\hline Jumlah/Total & 153 & 162 & 311 & 133 & 387 & 72 & 208 & 1,426 \\
\hline
\end{tabular}

Sumber: Data primer dioleh (2011)

Source: Primary data processed (2011) 
Mengacu pada Jankowski (1995) dan Subandar (2002), pendekatan MCDM dalam pelaksanaan penelitian ini dibagi kedalam tiga tahapan, yaitu: (a) penentuan (penetapan) alternatif, (b) penentuan nilai (skor) masingmasing kriteria, dan (c) prioritas pembuatan keputusan (decision making preferences). Alternatif yang ditetapkan merupakan pilihan-pilihan yang relevan, kriteria-kriteria dipergunakan untuk membandingkan berbagai pilihan, sedangkan nilai dimaksudkan untuk memberikan pembedaan bobot untuk setiap kriteria.

Faktor-faktor yang menjadi pertimbangan penentuan prioritas pengelolaan sumber daya terumbu karang di wilayah COREMAP dilakukan dengan metode scoring atau pembobotan yang merupakan penyatuan dari berbagai parameter yang terkait. Skor yang digunakan untuk penilaian terhadap elemen yang diteliti dinyatakan secara numeric (skala 1 hingga 9) dengan menggunakan skala Saaty (1991) seperti dijabarkan pada Tabel 2 .

\section{PENGELOLAAN SUMBER DAYA TERUMBU KARANG MELALUI PROGRAM COREMAP}

Pengelolaan terumbu karang di Indonesia saat ini dilakukan melalui Program Rehabilitasi dan Pengelolaan Terumbu Karang atau lebih dikenal dengan sebutan Coral Reef Rehabilitation and Management Program (COREMAP). COREMAP adalah program jangka panjang yang diprakarsai oleh Pemerintah Indonesia dengan tujuan untuk melindungi, merehabilitasi, dan mengelola pemanfaatan secara lestari terumbu karang serta ekosistem terkait di Indonesia, yang pada gilirannya akan menunjang kesejahteraan masyarakat pesisir (Anonim, 2012). COREMAP didanai oleh Pemerintah Indonesia dengan mendapat dukungan dari beberapa donor yakni: World Bank, Asia Development Bank, dan AusAID (Australia Agency for International Development).

COREMAP II ini diharapkan sebagai fase 'percepatan' yang didasarkan dan dikembangkan dari pengalaman pada fase inisiasi COREMAP I pada tahun 1998 2004. Tujuan dari fase II ini adalah untuk mengembangkan suatu sistem pengelolaan terumbu karang yang handal pada 6 prioritas Kabupaten Peserta melalui suatu program yang dibiayai secara berkelanjutan dengan koordinasi secara nasional tetapi implementasi secara desentralisasi, agar memberdayakan dan menyokong masyarakat pesisir secara berkelanjutan dalam pemanfaatan terumbu karang dan sumber daya ekosistem terkait. Dengan demikian kerusakan ekosistem terumbu karang dapat direhabilitasi dan dikonservasi yang pada gilirannya kehidupan masyarakat pesisir dapat ditingkatkan. Hal ini berarti akan terjadi perubahan perilaku masyarakat pesisir dari kebiasaan merusak terumbu karang tanpa rasa bersalah menjadi

\section{Tabel 2. Penilaian Terhadap Elemen-Elemen Penelitian.}

\section{Table 2. Assessment to Elements of the Research.}

\begin{tabular}{cl}
$\begin{array}{c}\text { Skala Perbandingan Numerik/ } \\
\text { Numerical Scale Comparison }\end{array}$ & \multicolumn{1}{c}{ Definisi/ Definition } \\
\hline 1 & Tidak penting/Unimportant \\
3 & Sedikit lebih penting/ Slightly more important \\
5 & Jelas lebih penting/ Clearly more important \\
7 & Sangat jelas lebih penting/ Very clearly more important \\
9 & Mutlak lebih penting/Absolutely more important \\
$2,4,6,8$ & Merupakan nilai-nilai diantara dua pertimbangan yang \\
& berdekatan (ragu-ragu)/A value judgment between two \\
\end{tabular}

Sumber : Saaty (1991)/Source : Saaty (1991) 
kesadaran memanfaatkannya dengan menjaga kelestarian terumbu karang. Oleh karena itu salah satu indikator keberhasilan program COREMAP ini selain indikator pengelolaan dan perberdayaan serta indikator biofisik adalah indikator sosial ekonomi dan kemiskinan, melalui 2 hal yaitu : 1) standar pendapatan dan kehidupan pada masyarakat pesisir target lebih besar dari masyarakat yang tidak ikut program dan sebelum adanya program; dan 2) persepsi dari nelayan ataupun masyarakat target di lokasi program terhadap kondisi keperluan hidup dan ekonomi.

COREMAP II dengan pendanaan WB ini dilaksanakan di 7 Kabupaten yang termasuk dalam 4 provinsi di Indonesia bagian Timur: (1) Pangkep dan (2) Selayar di Provinsi Sulaesi Selatan; (3) Buton dan (4) Wakatobi di Provinsi Sulawesi Tenggara; (5) Sikka di Provinsi Nusa Tenggara Timur; (6) Raja Ampat di Propinsi Papua Barat; dan (Biak) di Provinsi Biak. Proyek ini juga memberi dukungan untuk Dukungan Taman Laut di: (1) TNL Wakatobi di Kabupaten Wakatobi; (2) TNL Takabonerata di Kabupaten selayar; (3) KSDA Raja Ampat di Kabupaten Raja Ampat; (4) KSDA Padaido Biak di Kabupaten Biak; (5) KSDA Kapoposang di Kabupaten Pangkep dan (6) KSDA Maumere di Kabupaten Sikka.

Organisasi pelaksana proyek COREMAP dipimpin oleh seorang Direktur yang dibantu oleh 4 Deputi yang bertanggung jawab terhadap pelaksanaan kegiatan di bidang Manajemen Terumbu Karang dan CRITC (Coral Reef Information and Training Center), Pengikutsertaan Masyarakat, Kelembagaan, dan bidang Penegakan Hukum. Masing-masing Deputi dibantu oleh 2 orang asisten Deputi. Direktur dibantu oleh Sekretariat yang dipimpin oleh Kepala Sekretariat. Selain itu, organisasi pelaksana ini diperkuat oleh Financial Analyst yang mengelolah dana bantuan asing dan sejumlah konsultan yang direkrut untuk membantu pelaksanaan dan penyempurnaan konsep COREMAP.

Organisasi pelaksana ini dikenal sebagai PMO (Project Management Office) atau kantor pengelola proyek. Anggota PMO berasal dari berbagai instansi dilingkungan LIPI, Bappenas, Dirjen Bangda Depdagri, Dirjen Perikanan, Angkatan Laut RI, dan PHPA - Dirjen Kehutanan. Tugas dan tanggung jawab masing-masing anggota PMO telah dijabarkan seperti tertera dalam Surat Keputusan Kepala Puslitbang Oseanologi LIPI. Surat keputusan tersebut masih bersifat sementara sambil menunggu Surat Keputusan yang akan dikeluarkan oleh ketua LIPI. Rencana kerja PMO mengacu pada rencana kerja yang telah tercantum dalam DIP dan dalam kesepakatan dengan Bank Dunia dan ADB.

Mengingat bahwa kegiatan COREMAP akan berlangsung di daerah, dalam hubungan ini telah dipersiapkan Memo Kesepakatan antara Komite Pengarah COREMAP dangan Tim COREMAP Propinsi dibawah koordinasi Gubernur atau Ketua Bappeda Tingkat I dan Komite Pengarah COREMAP dengan tim COREMAP Kabupaten di bawah koordinasi Bupati atau Ketua Bappeda Tingkat II.

Kegiatan pengelolaan terumbu karang melalui COREMAP adalah pengelolaan yang berbasis masyarakat dengan proses dimulai dari masyarakat (bottom up). Tiap-tiap desa dibimbing oleh 1 orang pendamping (fasilitator). Fasilitator dibantu oleh perangkat-perangkat kelembagaan yang melibatkan masyarakat desa sebagaimana disajikan pada Tabel 3.

\section{EVALUASI PENGELOLAAN TERUMBU KARANG}

Hasil evaluasi kegiatan COREMAP II yang berakhir tahun 2011 telah berhasil memenuhi target biofisik, pemberdayaan dan pengentasan kemiskinan (Anonimous, 2011). COREMAP II telah berhasil melakukan berbagi kegiatan yaitu membentuk daerah perlindungan laut meningkat secara substansial, melembagakan kegiatan COREMAP secara berkelanjutan, meningkatkan kesadaran masyarakat akan pentingnya sumber daya laut. Kegiatan COREMAP II juga telah meningkatkan sosial ekonomi dan menurunkan tingkat kemiskinan melalui peningkatan pendapatan dan kesejahteraan di masa yang akan datang. 
Tabel 3. Perangkat Kelembagaan yang Mendukung Fasilitator dalam Program COREMAP. Table 3. Institutional Devices Supporting to Facilitator in the COREMAP Program.

\begin{tabular}{|c|c|c|}
\hline No & Nama/Name & Tugas/ Job Description \\
\hline 1 & $\begin{array}{l}\text { Motivator/ } \\
\text { Motivator }\end{array}$ & $\begin{array}{l}\text { Memberikan motivasi kepada masyarakat di desanya agar } \\
\text { dapat menjaga kelestarian terumbu karang / Provide motiva- } \\
\text { tion to the people in the village in order to preserve sustainabil- } \\
\text { ity of coral reefs }\end{array}$ \\
\hline 2 & $\begin{array}{l}\text { Pengamat karang/ } \\
\text { Reef Watcher }\end{array}$ & $\begin{array}{l}\text { Memantau keadaan karang dan melaporkan kejadian peru- } \\
\text { sakan karang seperti pengeboman dan penggunaan alat tang- } \\
\text { kap trawl / Monitor the state of coral reefs and report incidents } \\
\text { of reef destruction such as bomb and the use of trawl gear }\end{array}$ \\
\hline 3 & $\begin{array}{l}\text { Kelompok Masyarakat (Pok- } \\
\text { mas) Produksi/ Community } \\
\text { group of production }\end{array}$ & $\begin{array}{l}\text { Memanfaatkan dan meningkatkan potensi desa serta pengelo- } \\
\text { laannya secara optimal dengan dasar pengelolaan yang ramah } \\
\text { lingkungan / Utilize and optimize environment management }\end{array}$ \\
\hline 4 & $\begin{array}{l}\text { Pokmas Konservasi / } \\
\text { Community group of } \\
\text { conservation }\end{array}$ & $\begin{array}{l}\text { Menjaga lingkungan dan potensi desa, kelestarian sumber daya } \\
\text { alam darat dan laut serta keseimbangannya / Protecting the } \\
\text { environment and the natural resources }\end{array}$ \\
\hline 5 & $\begin{array}{l}\text { Pokmas Gender / } \\
\text { Community group of gender }\end{array}$ & $\begin{array}{l}\text { Meningkatkan kesejahteraan keluarga dan perbaikan pola hid- } \\
\text { up keluarga dengan pemberdayaan dan pengakuan hak kaum } \\
\text { perempuan di desa untuk dapat berperan dalam pembangunan } \\
\text { desa / Improvement family welfare with empowerment and } \\
\text { recognize the women in the village development }\end{array}$ \\
\hline 6 & $\begin{array}{l}\text { Dewan Pertimbangan Desa / } \\
\text { Village Advosory Council }\end{array}$ & $\begin{array}{l}\text { Memberikan masukan secara aktif dan pertimbangan-pertim- } \\
\text { bangandalam proses penyusunan Rencana Pengelolaan terum- } \\
\text { bu karang terpadu / Actively providing input and considerations } \\
\text { in the process of coral reef integrated management plan. }\end{array}$ \\
\hline
\end{tabular}

Sumber: COREMAP (2001); Yuniarti (2007)/ Source: COREMAP (2001); Yuniarti (2007)

Bagian sosial ekonomi CRITC LIPI mengukur pendapatan rumah tangga anggota Pokmas, yang menerima dana LKM. Survei dilakukan untuk 180-250 rumah tangga di setiap kabupaten. Jumlah rumah tangga sampel di 7 (tujuh) kecamatan adalah 1.605. Temuan menunjukkan bahwa pendapatan rumah tangga anggota kelompok penerima manfaat meningkat sebesar $33,9 \%$ di semua kabupaten. Jika penyesuaian untuk inflasi dibuat, pendapatan meningkat sebesar $20,8 \%$. Karena pendapatan di luar proyek mungkin telah meningkat juga, CRITC LIPI membandingkan hasilnya dengan data pendapatan daerah rata-rata. Persepsi stakeholder terhadap kegiatan COREMAP juga sangat positif. Hal ini menunjukkan bahwa tidak hanya intervensi Proyek langsung memiliki dampak menyehatkan, tetapi juga bahwa konsep- konsep umum tentang sumber daya laut dan perlindungan terumbu karang dipahami dan diterima.

Hasil pengamatan dilapangan menunjukkan bahwa meskipun ada kegiatan masyarakat di wilayah daratan utama dan pulau-pulau kecil seperti adanya perkebunan cengkah dan lada di KKLD juga berpotensi menyebabkan pencemaran limbah yang berasal penggunaan pupuk dan bahan anorganik lainnya. Selain itu terdapat pula potensi bahan pencemar yang berasal dari tumpahan minyak pelumas / BBM yang berasal dari kapal-kapal nelayan dan penumpang yang beroperasi di wilayah tersebut. Namun sejauh ini belum diketahui seberapa jauh pengaruhnya terhadap terumbu karang yang ada. 
Meskipun demikian ada hal-hal yang perlu mendapat perhatian dari berbagai pihak. Hasil pengamatan langsung dilapangan menunjukkan adanya aktivitas pembuangan limbah industri yang berpotensi mencemari perairan masyarakat/ pengusaha, meskipun dalam jumlah yang terbatas. Selain itu ada juga wilayah-wilayah yang belum semua masyarakat dapat memanfaatkan potensi usaha di sektor perikanan berupa kegiatan penangkapan ikan yang dilakukan oleh nelayan lokal dan nelayan pendatang dari sekitar KKLD. Penyebab lain dari kerusakan terumbu karang di KKLD adalah adanya kegiatan pariwisata. Walaupun belum berkembang, namun kegiatan ini berpotensi besar turut sebagai penyebab kerusakan. Anggraini (2012) menyebutkan bahwa kegiatan wisata baik itu berupa kegiatan jalan-jalan di pantai, berenang, snorkling, ataupun menyelam di terumbu karang, jika tidak dikelola dengan baik, dapat merusak terumbu karang. Wisatawan akan membuang sampah tidak pada tempatnya. Mereka juga dapat menginjak-injak, menyentuh, membunuh, ataupun dan mengambil karang dan biota laut lainnya.

\section{PELUANG DAN ALTERNATIF PENGELOLAAN}

Model pengelolaan sumber daya dengan berbagai kegiatan pemanfaatan terumbu karang oleh masyarakat yang mengarah pada ketidakberlanjutan mata pencaharian di masa yang akan datang, seperti usaha perikanan tangkap bila dalam pengelolaan tidak ada peningkatan skala usaha. Sedangkan untuk kegiatan wisata bahari, terindikasi kondisinya tidak berkelanjutan, jika tidak menjaga kelestarian terumbu karang yang menjadi objek daya tarik wisata (ODTW) di wilayah sekitar terumbu karang. Oleh karena itu model pengelolaan yang dapat dijadikan alternatif adalah model pengelolaan sumber daya berbasis sistem sosial-ekologis yang memasukkan komponen dalam sistem sosial-ekologis, kerentanan dan resiliensi, sebagai dasar pertimbangan dalam membuat keputusan.Selanjutnya dengan analisis MCDM disusun model pengelolaan sumber daya terumbu karang dalam bentuk hirarki (Gambar 3).

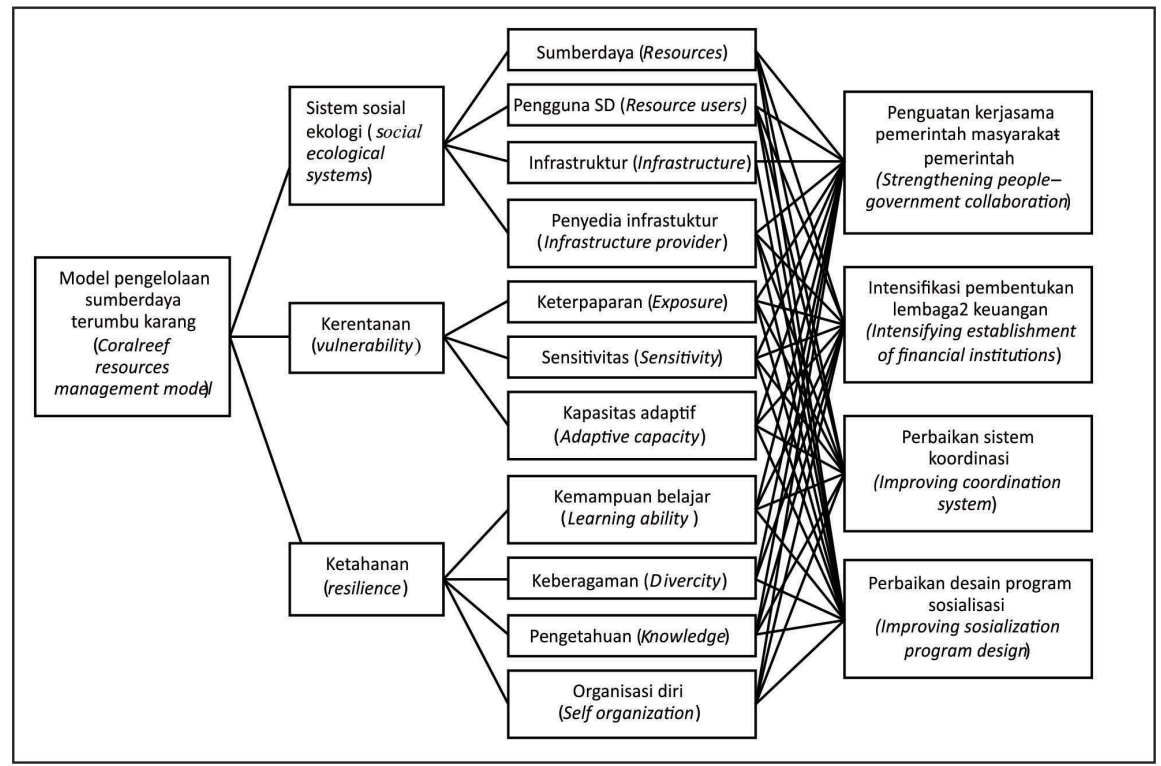

Gambar 3. Struktur Hirarki Untuk MCDM Pada Keberlanjutan Pengelolaan Sumber Daya Terumbu Karang di Kawasan Coral Triangle, 2011.

Figure 3. MCDM Hierarchical Structure of Coral Reef Resource Management Sustainability in the Coral Triangle Area, 2011. 
Hirarki yang disusun menggambarkan bentuk pengelolaan yang sebaiknya dilakukan di wilayah COREMAP. Pada level pertama, menggambarkan tujuan pengelolaan yang ingin dicapai yaitu pengelolaan sumber daya khususnya sumber daya terumbu karang yang berkelanjutan. Pada level kedua, menggambarkan kriteria yang menjadi dasar penentuan bentuk pemanfaatan yang sebaiknya dilakukan, meliputi kriteria sistem sosialekologis, kerentanan dan resiliensi. Pada level ketiga, menggambarkan sub kriteria yang berpengaruh pada keputusan untuk menentukan bentuk kegiatan pemanfaatan sumber daya. Pada setiap kriteria, terdapat dua sub kriteria yang dominan dalam pengambilan keputusan. Sedangkan pada level keempat, menggambarkan rekomendasi kebijakan dalam pengelolaan pemanfaatan sumber daya yang sebaiknya dilakukan di wilayah COREMAP.

Berdasarkan kriteria-kriteria yang telah ditentukan, kemudian diberikan bobot pada setiap pilihan kriteria, sub kriteria sampai alternatif rekomendasinya. Dari hasil pembobotan, yang bertujuan untuk mengetahui bentuk pengelolaan sumber daya terumbu karang di wilayah COREMAP, memberikan hasil bahwa kriteria resiliensi merupakan kriteria yang bobotnya paling tinggi, dibanding nilai bobot dari kriteria sistem sosial-ekologi dan kriteria kerentanan. Nilai bobot masing-masing kriteria, berturut-turut adalah SES bobotnya 0,350 , kerentanan bobotnya 0,249 dan resiliensi bobotnya 0,401 . Hasil pembobotan terhadap masing-masing kriteria selengkapnya disajikan pada Tabel 4 berikut ini.

Tabel 4. Nilai Bobot Kriteria dan Sub Kriteria Untuk Pengelolaan Sumber Daya Terumbu Karang di Wilayah COREMAP.

Table 4. Weighting Value of Criteria and Sub Criteria For Coral Reef Resources Management in the COREMAP region.

\begin{tabular}{|c|c|c|}
\hline No & Kriteria dan Sub Kriteria/ Criteria and Sub Criteria & Bobot / Value \\
\hline 1 & Sistem Sosial-Ekologi (SES) / Social-ecological systems & 0.350 \\
\hline a & Sumber daya / Resources & 0.097 \\
\hline$b$ & Pengguna sumber daya / Resource user & 0.097 \\
\hline c & Infrastruktur / Infrastructure & 0.084 \\
\hline$d$ & Penyedia infrastruktur / Infrastructure providers & 0.072 \\
\hline 2 & Kerentanan / Vulnerability & 0.249 \\
\hline a & Keterpaparan / Exposure & 0.071 \\
\hline$b$ & Sensitivitas / Sensitivity & 0.083 \\
\hline c & Kapasitas adaptif / Adaptive capacity & 0.095 \\
\hline 3 & Resiliensi / Resilience & 0.401 \\
\hline a & $\begin{array}{l}\text { Kemampuan belajar hidup dengan perubahan dan ketidakpastian / } \\
\text { Learning to live with change and uncertainty }\end{array}$ & 0.119 \\
\hline$b$ & $\begin{array}{l}\text { Keberagaman untuk reorganisasi dan pembaharuan / Nurturing } \\
\text { diversity for reorganization and renewal }\end{array}$ & 0.104 \\
\hline c & $\begin{array}{l}\text { Mengkombinasikan berbagai macam pengetahuan / Combining } \\
\text { different types of knowledge for learning }\end{array}$ & 0.104 \\
\hline$d$ & $\begin{array}{l}\text { Mengkreasi peluang untuk organisasi diri / Creating opportunity } \\
\text { for self-organization }\end{array}$ & 0.074 \\
\hline
\end{tabular}

Sumber: Diolah dari data primer. 2011/ Source: Primary data processed (2011) 
Bobot pada sub kriteria dari masingmasing kriteria yang ada menunjukkan bahwa pada kriteria resiliensi, sub kriteria kemampuan belajar memperoleh bobot tertinggi yaitu 0,119 , selanjutnya sub kriteria keberagaman dan pengetahuan masing-masing sebesar 0,104 , dan terakhir sub kriteria organisasi diri sebesar 0,074. Untuk kriteria SES, sub kriteria yang mendapat bobot tertinggi adalah sumber daya dan pengguna sumber daya masing-masing sebesar 0,097, disusul oleh sub kriteria infrastruktur sebesar 0,084 dan terakhir sub kriteria penyedia infrastruktur yang hanya mendapat bobot 0,072 . Sedangkan pada kriteria kerentanan, sub kriteria yang menunjukkan bobot tertinggi adalah kapasitas adaptif sebesar 0,095, selanjutnya sub kriteria sensitivity sebesar 0,083 dan terendah bobotnya adalah exposure yaitu sebesar 0,071 .

Nilai bobot tersebut mengindikasikan bahwa kriteria ekonomi merupakan kriteria yang paling penting dibanding dengan kriteria yang lain, khususnya dalam model pengelolaan sumber daya perikanan berbasis sistem sosialekologi. Beberapa sub kriteria yang berada dalam kriteria SES seperti sumber daya, pengguna sumber daya, infrastruktur dan penyedia infrastruktur. Sub kriteria sumber daya dan pengguna sumber daya merupakan hal yang paling berpengaruh dalam pengelolaan sumber daya terumbu karang di wilayah COREMAP. Hal ini menunjukkan bahwa faktor ketersediaan sumber daya dan perilaku pemanfaatan oleh pengguna sumber daya merupakan hal yang dominan (Gambar 4).

Selanjutnya adalah beberapa sub kriteria yang berada dalam kriteria kerentanan seperti exposure, sensitivity dan kapasitas adaptif. Sub kriteria kapasitas adaptif merupakan hal yang paling berpengaruh dalam pengelolaan sumber daya terumbu karang di wilayah COREMAP (Gambar 5). Hal ini menunjukkan bahwa faktor kapasitas adaptif dalam hal kerentanan merupakan hal yang dominan.

Beberapa sub kriteria yang berada dalam kriteria resiliensi adalah kemampuan belajar, pengetahuan, keberagaman dan organisasi diri. Sub kriteria kemampuan belajar dan pengetahuan merupakan hal yang paling berpengaruh dalam pengelolaan sumber daya terumbu karang di wilayah COREMAP. Hal ini menunjukkan bahwa faktor kemampuan belajar dan pengetahuan menghadapi kondisi ekologis yang ada terutama pada saat terjadi perubahan ketersediaan merupakan hal yang dominan (Gambar 6).

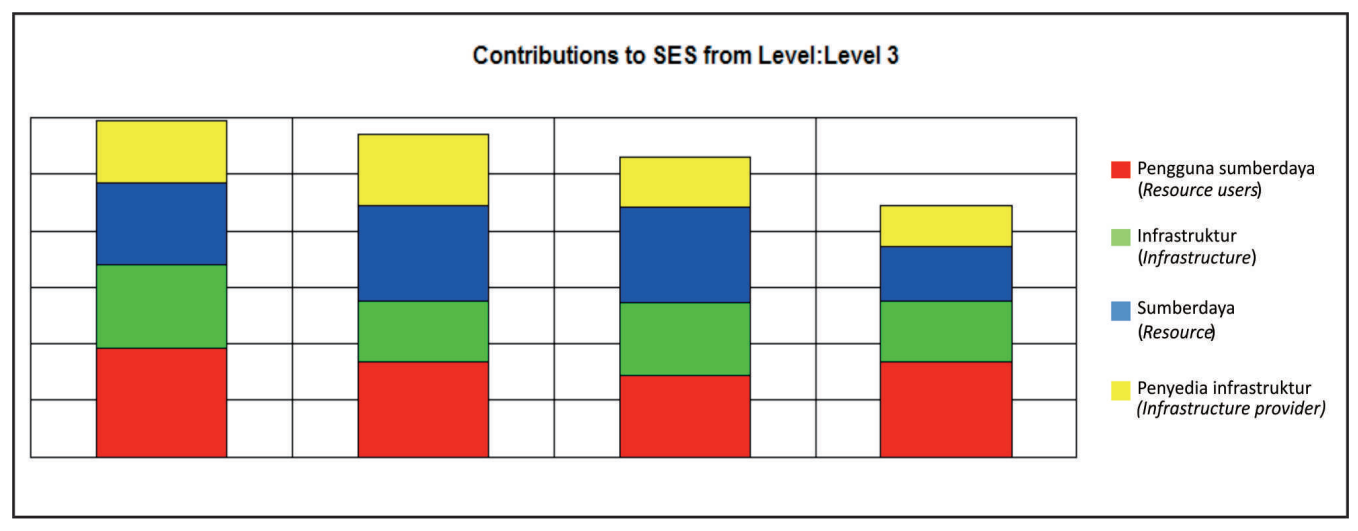

Gambar 4. Skor Akhir Prioritas Model Pengelolaan Sumber Daya Untuk Kriteria SES di Wilayah Coral Triangle, 2011.

Figure 4. Final Score of Resource Management Models Priority for SES Criterias in the Coral Triangle Area, 2011. 


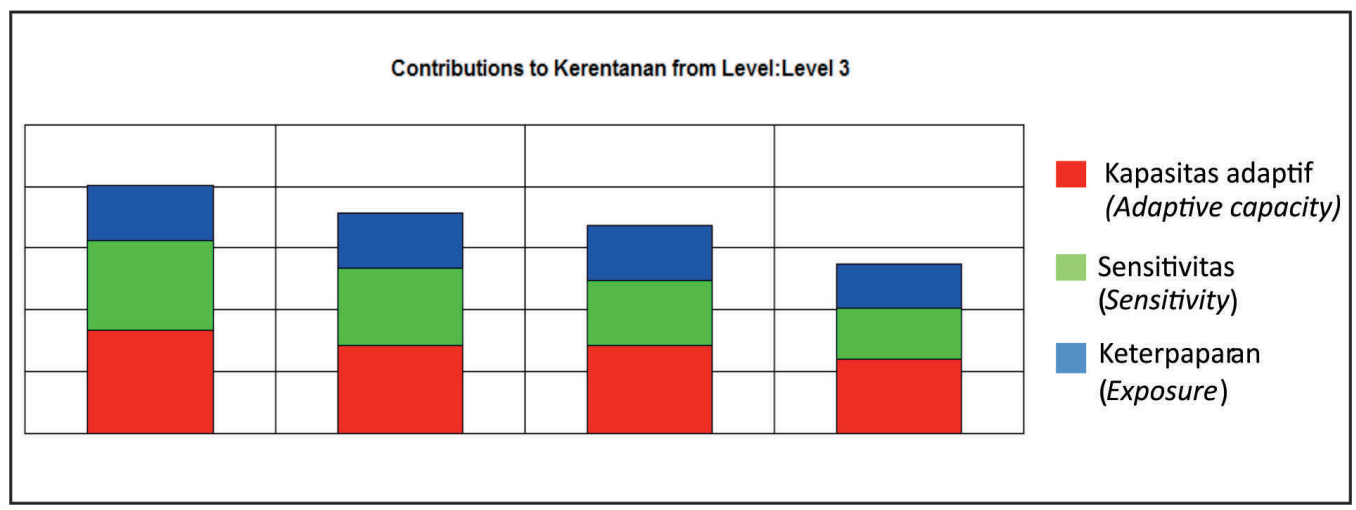

Gambar 5. Skor Akhir Prioritas Model Pengelolaan Sumber Daya Untuk Kriteria Kerentanan di Wilayah Coral Triangle, 2011.

Figure 5. Final Score of Resource Management Models Priority for Vulnerability Criterias in the Coral Triangle Area, 2011.

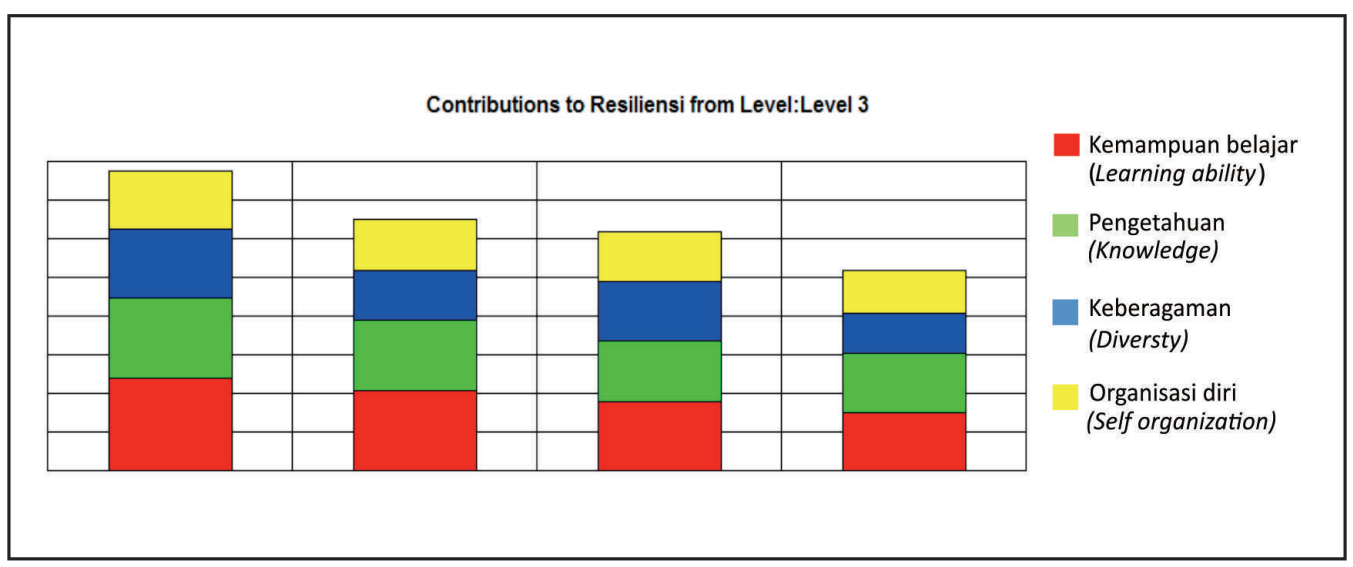

Gambar 6. Skor Akhir Prioritas Model Pengelolaan Sumber Daya Untuk Kriteria Resiliensi di Wilayah Coral Triangle, 2011.

Figure 6. Final Score of Resource Management Models Priority for Resilience Criterias in the Coral Triangle Area, 2011.

Setelah melakukan analisis berdasarkan kriteria dan sub kriteria, membandingkan antara masing-masing kriteria, tahap selanjutnya adalah mencari alternatif terbaik berdasarkan pada seluruh kriteria yang menjadi dasar dalam penentuan kebijakan pengelolaan sumber daya terumbu karang di wilayah COREMAP. Dari hasil analisis menunjukkan bahwa susunan peringkat pemanfaatan sumber daya terumbu karang di wilayah COREMAP dengan menggunakan teknik SMART, prioritas pertama adalah penguatan kerjasama antara masyarakat dan pemerintah dengan bobot tertinggi sebesar 0,873. Urutan kedua model pengelolaan adalah melakukan perbaikan sistem koordinasi dengan bobot 0,789 . Alternatif ketiga adalah melakukan perbaikan desain program sosialisasi dengan bobot 0,753 . Dan alternatif terakhir dengan bobot 0,618 adalah melakukan intensifikasi pembentukan lembaga-lembaga keuangan. 
Decision: Model Pengelolaan SD TK

\begin{tabular}{|c|c|c|}
\hline Alternatives & Value & Decision Scores \\
\hline $\begin{array}{l}\text { Penguatan kerjasama pemerintah } \\
\text { masyarakat-pemerintah } \\
\text { (Strengthening people - government } \\
\text { collaboration) }\end{array}$ & 0.873 & \\
\hline $\begin{array}{l}\text { Intensifikasi pembentukan lembaga-lembaga } \\
\text { keuangan (Intensifying establishment of } \\
\text { financial institutions) }\end{array}$ & 0.618 & \\
\hline $\begin{array}{l}\text { Perbaikan sistem koordinasi } \\
\text { (Improving coordination system) }\end{array}$ & 0.789 & \\
\hline $\begin{array}{l}\text { Perbaikan desain program sosialisasi } \\
\text { (Improving sosialization program design) }\end{array}$ & 0.753 & \\
\hline
\end{tabular}

\section{Gambar 7. Bentuk Pengelolaan Sumber Daya Terumbu Karang di Wilayah Coral Triangle Dengan Teknik SMART, 2011.}

Figure 7. Form of Coral Reef Resources Management in the Coral Triangle Area With SMART Technique, 2011.

\section{KEBIJAKAN ANTISIPATIF MODEL PENGELOLAAN}

Penelitian yang dilakukan oleh Purnomo et al., (2011) tentang Pengembangan Model Pengelolaan Sumber daya Perikanan Berbasis Sistem Sosial-Ekologi di Wilayah CTI dalam Antisipasi terhadap Perubahan iklim menunjukkan hasil sebagai berikut: di ketujuh lokasi yang telah disurvey (Kabupaten Pangkep, Kabupaten Wakatobi, Kabupaten Sikka, Kabupaten Selayar, Kabupaten Buton, Kabupaten Raja Ampat, dan Kabupaten Biak Numfor), kondisi sosial ekologis secara menonjol ditandai dengan adanya interaksi antara sumber daya dan pengguna sumber daya. Hal ini menguatkan pemahaman mengenai sistem sosial-ekologis yang disampaikan oleh Anderies et al (2004). Penghidupan pengguna dan kondisi sumber daya sangat saling mempengaruhi satu dengan lainnya. Masing-masing komponen, dengan segenap sub komponennya, berinteraksi satu dengan yang lain, yang secara bersama-sama menentukan kondisi dari sistem tersebut.
Ada indikasi keterkaitan sub-sub komponen sistem sosial ekologis yang mempengaruhi kerentanan dan resiliensi masyarakat. Dalam konteks hubungan manusia dengan alam, resiliensi merefleksikan derajat kemampuan sistem dalam membangun kapasitas belajar dan beradaptasi. Sebagian dari kapasitas tersebut terdapat pada kemampuan regenerasi dari ekosistem dan kemampuan untuk tetap menghasilkan sumber daya dan jasa yang esensial bagi kehidupan manusia dan pengembangan masyarakat di dalam perubahan-perubahan yang terjadi. Faktor tekanan alam di ketujuh lokasi mempengaruhi kerentanan dan resiliensi masyarakat. Tekanan alam yang teridentifikasi di semua lokasi penelitian yaitu pergantian musim yang tidak menentu, angin tornado, abrasi, sea level rise, gempa dan tsunami. Tekanan-tekanan alam yang ada membentuk tingkat resiliensi masyarakat yang berbedabeda dalam setiap masyarakat.

Ada indikasi bahwa kondisi kerentanan dan resiliensi masyarakat dapat mempengaruhi 
kerentanan dan resiliensi sumber daya. Ketergantungan yang kuat dari masyarakat terhadap sumber daya alam teridentifikasi di semua lokasi penelitian menyebabkan kerentanan mereka cukup tinggi terhadap berbagai tekanan dari luar, baik alam maupun lainnya. Hal ini mengindikasikan bahwa tinggi rendahnya kerentanan masyarakat, selain terkait dengan ketergantungan masyarakat pada alam dan perubahan yang terjadi pada alam, juga terkait dengan sejumlah faktor eksternal, di antaranya kebijakan pemerintah.

Intervensi pemerintah yang efektif mendukung kondisi sumber daya relatif lebih terjaga dan kerentanan menjadi lebih rendah. Salah satu contoh intervensi yang efektif tersebut adalah program-program penyadaran masyarakat yang dibarengi dengan pengembangan ekonomi alternatif yang sesuai dengan konteks lokal di sebagian lokasi penelitian. Di Wakatobi misalnya, eksploitasi sumber daya berhasil ditekan dan degradasi lebih lanjut relatif dapat dicegah. Hasil penelitian menunjukkan bahwa sebagian besar responden tidak setuju pengambilan terumbu karang dan penggunaan bahan/alat yang merusak. Meskipun masih ada sebagian masyarakat yang mengambil karang, baik dalam kondisi hidup atau mati.

Penurunan tingkat kerentanan di lokasilokasi yang secara efektif mendapatkan intervensi positif tersebut, di sisi sebaliknya menyebabkan kenaikan resiliensi masyarakat, yang diharapkan akan berdampak positif pada resiliensi ekologis terkaitnya, yang dalam hal ini adalah terumbu karang. Masyarakat dengan resiliensi tinggi ini diharapkan relatif lebih mampu untuk mengembangkan penghidupan dangan cara yang variatif sehingga tekanan terlalu besar pada sumber daya dapat dikurangi. Selanjutnya, kondisi sumber daya yang kembali membaik tersebut juga terdeteksi telah mengembalikan peluangpeluang ekonomi yang hilang pada periode di mana sumber daya mengalami penurunan. Hasil monitoring ekologi terumbu karang di Raja Ampat (Prayudha dan Picasauw, 2009) menunjukkan bahwa kondisi karang hidup mengalami kenaikan nilai persentase tutupan karang hidupnya.

Secara umum, rangkuman hasil analisis tersebut di atas mengindikasikan adanya rangkaian interaktif antar komponen dalam sistem sosial ekologis di ketiga lokasi, yang menunjukkan benang merah antara berbagai kejadian, yang menunjukkan pula kejadian atau interaksi antar kejadian yang mengarah pada kerentanan atau resiliensi tertentu. Hasil ini dapat dijadikan dasar untuk pengembangan sebuah model yang memungkinkan pendugaan kerentanan dan resiliensi yang dihubungkan dengan kondisi komponen-komponen ekologis, faktor eksternal tertentu dan interaksi di antaranya. Terkait dengan judul dan tujuan penelitian ini, faktor eksternal tertentu tersebut adalah perubahan iklim.

Setelah melakukan analisis berdasarkan kriteria dan sub kriteria, membandingkan antara masing-masing kriteria, tahap selanjutnya adalah mencari alternatif terbaik berdasarkan pada seluruh kriteria yang menjadi dasar dalam penentuan pengelolaan sumber daya terumbu karang di wilayah COREMAP. Kriteria yang dimaksudkan adalah sistem sosial ekologis, kerentanan dan resiliensi. Sub kriteria sistem sosial ekologis adalah sumber daya, pengguna sumber daya, prasarana dan penyedia prasarana. Sub kriteria kerentanan adalah exposure, sensitivitas dan kapasitas adaptasi. Dan sub kriteria resiliensi adalah kemampuan belajar hidup dalam perubahan dan ketidakpastian, kemampuan untuk mengembangkan diversitas yang memungkinkan terjadinya reorganisasi dan pembaruan, kemampuan untuk memanfaatkan berbagai macam pengetahuan secara terpadu dan kemampuan menciptakan peluang untuk pengorganisasian diri. Hal ini bisa dilihat dari penambahan pengetahuan dan wawasan masyarakat dengan adanya pelatihan mengenai kegiatan usaha ekonomi yang bisa dijadikan sebagai mata pencaharian alternatif dan memberikan manfaat yang meluas bagi masyarakat lainnya. Di Buton misalnya, selain berprofesi utama sebagai nelayan, masyarakat juga mempunyai pendapatan lain dari usaha budidaya rumput laut. Bahkan ada yang menjadi 
pedagang emas dan pakaian ke daerah lain yang dilakukan oleh anggota keluarga lain.

Hasil penelitian ini merekomendasikan pada program COREMAP agar memberdayakan dan mendukung masyarakat pesisir secara berkelanjutan dalam pemanfaatan terumbu karang dan sumber daya ekosistem terkait yang berada di wilayah Coral Triangle, yang dilaksanakan melalui strategi sebagai berikut:

1. Peningkatan efektivitas KKLD/ TWAL melalui penguatan kerjasama masyarakat-pemerintah dalam upayaupaya penciptaan menciptakan mata pencaharian alternatif, terutama di sektor non konvensional terutama pariwisata. Melalui kerja sama yang erat, diharapkan masyarakat merasa memiliki sehingga masyarakat tidak hanya menerima manfaat saja. Diharapkan masyarakat difasilitasi untuk terlibat secara lebih berarti. Hal yang juga perlu diperhatikan adalah membangun hubungan kerja sama dengan berbagai komponen masyarakat dan lembaga yang ada di tingkat lokal yaitu pemerintahan desa dan meningkatkan kesadaran masyarakat bahwa dengan dibuatnya KKLD/TWAL, masyarakat telah ikut menjaga stabilitas kelestarian lingkungan dan keberlanjutan ekologi. Langkah konkrit yang dapat dilakukan diantaranya adalah: meningkatkan akses masyarakat terhadap aset produktif, memperkuat posisi nelayan dalam transaksi dan dalam bermitra usaha, peningkatan pelayanan pendidikan dan kesehatan, pengembangan industri di pedesaan dalam rangka memperkuat industri rakyat, dan mendorong tumbuhnya jiwa wirausaha.

2. Memfokuskan pada intensifikasi pembentukan lembaga-lembaga keuangan yang mendukung permodalan usaha dan perbaikan teknologi. Lembaga keuangan yang dibentuk dapat memberikan bantuan finansial sesuai dengan kebutuhan masyarakat, bersifat in-formal, dapat dikelola oleh nelayan sendiri untuk mempermudah efektivitas dan efisiensi terhadap capaian sasaran

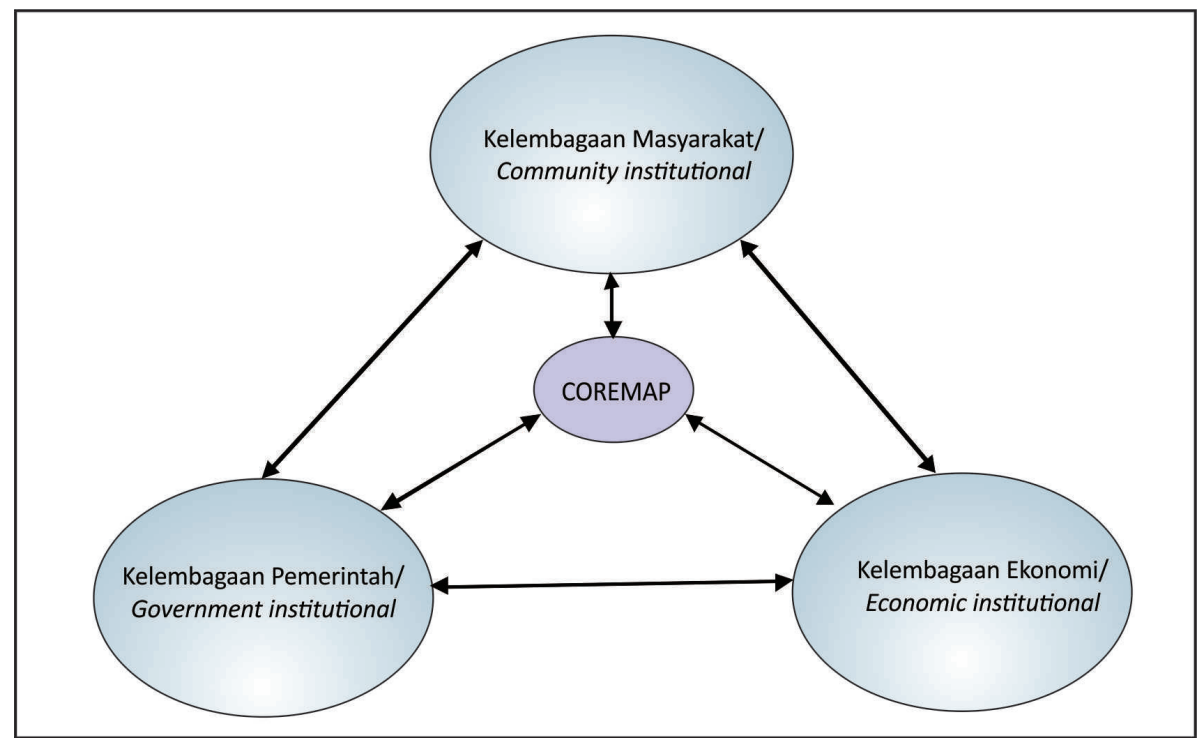

Gambar 8. Diagram Sistem Koordinasi Kelembagaan Pengawasan Sumber Daya Terumbu Karang di Wilayah COREMAP.

Figure 8. Diagram Of The Coordinate System of Institutional Monitoring of Coral Reef Resources in the COREMAP Region. 
dengan tetap menjaga ketertiban administrasi. Penyaluran bantuan melalui satu pintu, sehingga memudahkan pengawasan dan perencanaan untuk keberlanjutan lembaga keuangan yang telah dibentuk. Masyarakat sendiri mudah untuk mengakses terhadap modal finasial yang dibutuhkan.

3. Perbaikan sistem koordinasi pihak terkait (Polairud, Dinas Kelautan dan Perikanan, TNI AL, dsb) dalam pengawasan terhadap sumber daya. Strategi ini dapat dicapai melalui pembentukan suatu sistem kelembagaanyang mendukung kehidupan masyarakat dengan mempertimbangkan kelembagaan masyarakat, ekonomi dan pemerintah seperti yang dapat dilihat pada Gambar 8.

Pada Gambar 8 dapat dilihat bahwa Pemerintah Daerah memiliki fungsi dan peran melakukan koordinasi pengawasan sumber daya, dengan mengakomodir berbagai kelompok masyarakat (nelayan, tokoh masyarakat, organisasi non pemerintah atau LSM, dan akademisi). Selanjutnya kelembagaan masyarakat berperan untuk membangun kelompok masyarakat nelayan menjadi lebih produktif, memiliki etos kerja dan rasa kebersamaan. Kemudian kelembagaan ekonomi diarahkan untuk meningkatkan kegiatan ekonomi berbasis sumber daya setempat menjadi lebih baik.

4. Perbaikan desain program sosialisasi mengenai penggunaan alat tangkap ramah lingkungan. Sosialisasi atau pemasyarakatan program adalah tahapan penting dalam program pengembangan masyarakat pedesaan. Kegiatan sosialisasi tidak hanya menyampaikan informasi tentang penggunaan alat tangkap ramah lingkungan dan dampaknya, yang tentunya perlu dukungan dari berbagai kelompok masyarakat. Proses sosialisasi dapat dibagi dalam beberapa tahapan yang dapat dilakukan secara simultan sebagai berikut: pengenalan alat tangkap ramah lingkungan, kunjungankunjungan, melaksanakan kegiatan khusus, mendiskusikan temuan, dan menyusun laporan.

\section{PENUTUP}

Hasil penelitian ini merekomendasikan strategi pengelolaan berikut ini: 1) Peningkatan efektivitas KKLD/TWAL melalui penguatan kerjasama masyarakat-pemerintah dalam upaya-upaya penciptaan menciptakan mata pencaharian alternatif, terutama di sektor non konvensional terutama pariwisata; 2) Memfokuskan pada intensifikasi pembentukan lembaga-lembaga keuangan yang mendukung permodalan usaha dan perbaikan teknologi; 3) Perbaikan sistem koordinasi pihak terkait (Polairud, Dinas KP, TNI AL, dsb) dalam pengawasan terhadap sumber daya; dan 4) Perbaikan desain program sosialisasi mengenai penggunaan alat tangkap ramah lingkungan.

Strategi pelaksanaan pengelolaan terumbu karang di wilayah Coral Triangle dapat dilakukan menurut urutan prioritas. Prioritas pertama adalah penguatan kerjasama antara masyarakat dan pemerintah, prioritas kedua adalah melakukan perbaikan sistem koordinasi, prioritas ketiga adalah melakukan perbaikan desain program sosialisasi; dan prioritas keempat adalah melakukan intensifikasi pembentukan lembaga lembaga keuangan. Strategi tersebut dapat diakomodasikan ke dalam dokumen perencanaan program pengelolaan terumbu karang. Diharapkan dalam waktu 7-12 tahun kondisi terumbu karang berangsur pulih dan kehidupan sosial ekonomi masyarakat mengalami peningkatan.

\section{DAFTAR PUSTAKA}

Anonim. 1996. Criterium Decision Plus, The Complete Formulation, Analysis, and Presentation for Windows Version 3.04 Students Version Tutorial. Bellevue WA: Copyright 1995-1996 Info Harvest Inc.[pdf]. (http://www.infoharvest.com/ ihroot/infoharv/304Tutorial.pdf, diakses tanggal 11 Desember 2011). 
2012. http://www.coremap.or.id/tentang_ coremap/mengenal_coremap/, diakses tanggal 15 Juni 2012.

Anderies, J.M., M.A. Janssen, and E. Ostrom. 2004. A Framework to Analyze The Robustness of Social-Ecological Systems from An Institutional Perspective. Ecology and Society 9 (1), 18 [online] URL http:// www.ecologyandsociety.org/vol9/iss1/ art18/ .

Anggraini, K. 2012. Manfaat Terumbu Karang dan Ancamannya. Yayasan Terumbu Karang Indonesia (TERANGI). Jakarta.

Berkes, F., J. Colding and C. Folke. 2003. Navigating Social-Ecological Systems: Building Resilience for Complexity and Change. Cambridge University Press, Cambridge, UK.

Binder, L.W. and P. Dalton. 2011. Assessing the Vulnerability of Four West Coast Fisheries to Climate Change. Assessing the Vulnerability of West Coast Fisheries to a Changing Climate" Workshop on May 25 - 26, 2011. Climate Impacts Group. Seattle.

Dahuri R., J. Rais, S.G. Putra, dan M.J. Sitepu. 2001. Pengelolaan Sumber daya Wilayah Pesisir dan Lautan secara Terpadu. PT. Pradnya Paramita, Jakarta.

Dahuri, R. 2003. Keanekaragaman Hayati Laut: Aset Pembangunan Berkelanjutan Indonesia. PT Gramedia Pustaka Utama, Jakarta. 412 hal.

Departemen Kelautan dan Perikanan. 2004. Keputusan Menteri Kelautan dan Perikanan Nomor: KEP. 38/MEN/2004: Kebijakan Umum Pengelolaan Terumbu Karang di Indonesia. Departemen Kelautan dan Perikanan. Jakarta.

Edwards, W. and Barron, F. H. 1994. SMARTS and SMARTER: Improved Simple Methods for Multiattribute Utility Measurement. Organizational Behavior and Human Decision Processes, 60, 306-325.
Gumbriech, T. 1996. Application of GIS in Training for Environment Management. (46) p 17-30.

Jankowski, P. 1995. Integrating Geographical Information Systems and Multiple Criteria Decision Making Methods. International Journal Geo. Inform. Sys. 9(3), 251-273, 1995.

Kasim, M. 2011. COREMAP II vs MCRMP.( http:// marufkasim.blog.com/2011/06/26/ coremap-ii-vs-mcrmp/, diakses pada tanggal 5 Mei 2012).

King, M. 1995. Fisheries Biology, Assessment and Management. 2nd ed. Fishing News Books. Oxford. $382 \mathrm{p}$.

Lembaga Ilmu Pengetahuan Indonesia. 2011. Kondisi Terumbu Karang Indonesia. Lembaga Ilmu Pengetahuan Indonesia. Jakarta.

Ministri of Marine Affairs and Fisheries. 2011. Draft Implementation Completion Report. Project Management Office Coral Reef Rehabilitation and Management Program. Directorate General of Marine, Coasts and Small Island. Ministri of Marine Affairs and Fisheries. Jakarta.

Prayudha, B. dan B. Picasauw. 2009. Monitoring Terumbu Karang Rajaampat (Waigeo Selatan). Coral Reef Rehabilitation and Management Program II - Lembaga IImu Pengetahuan Indonesia. Jakarta.

Purnomo, A.H., S.H. Suryawati, R.A. Wijaya, E.S. Luhur, Nurlaili, A. Wahyono, L. Adrianto, Triyono, F. Nurhabni dan R. Triyanti. 2011. Pengembangan Model Pengelolaan Sumber daya Perikanan Berbasis Sistem Sosial-Ekologi di Wilayah CTI dalam Antisipasi terhadap Perubahan iklim. Laporan Teknis. Balai Besar Penelitian Sosial Ekonomi Kelautan dan Perikanan. Badan Penelitian dan Pengembangan Kelautan dan Perikanan, Kementerian Kelautan dan Perikanan. Jakarta. 
Reid, C., J. Marshall, D. Logan dan D. Kleine. 2011. Terumbu Karang dan Perubahan Iklim; Panduan Pendidikan dan Pembangunan Kesadartahuan. Kerjasama Australian Government Department of Sustainability, Environment, Water, Population and Communities dengan Kementerian Kelautan dan Perikanan, The University of Queensland Australia dan Coralwatch.

Rudianto, E. 2009. Coral Triangle Initiative for Coral Reefs, Fisheries and Food Securities. Buletin Penataan Ruang Edisi 2e. Direktorat Tata Ruang Laut, Pesisir dan Pulau-Pulau Kecil, Departemen Kelautan dan Perikanan. Jakarta.

Saaty, T.L. 1991. Pengambilan Keputusan Bagi Para Pemimpin: Proses Hirarki Analitik untuk Pengambilan Keputusan dalam Situasi yang Kompleks. Seri Manajemen No. 134 (Terjemahan). Pustaka Binaman Pressindo. Jakarta.
Subandar, A. 2002. Multi Criteria Decision Making Techniques. Materi Kuliah PS-SPL. Bogor: Tidak diterbitkan. Institut Pertanian Bogor. Bogor. 22 hal.

Wahyono, A ., I.G.P. Antariksa, M. Imron, R. Indrawasih, dan Sudiyono. 2001. Pemberdayaan Masyarakat Nelayan. Penerbit Media Pressindo bekerjasama dengan Yayasan Adikarya IKAPI dan Ford Foundation. Jakarta.

Wilkinson, C. 2008. Status of Coral Reefs of The World: 2008. Global Coral Reef Monitoring Network and Reef and Rainforest Research Centre, Townsville, Australia, 296 p.

Yuniarti. 2007. Pengelolaan Wilayah Pesisir di Indonesia (Studi Kasus : Pengelolaan Terumbu Karang Berbasis Masyarakat di Kepulauan Riau). Makalah. Fakultas Perikanan dan Ilmu Kelautan Universitas Padjadjaran. Bandung. 